\title{
Short linear motifs - ex nihilo evolution of protein regulation
}

\author{
Norman E. Davey ${ }^{1 *}$, Martha S. Cyert ${ }^{2}$ and Alan M. Moses ${ }^{3,4}$
}

\begin{abstract}
Short sequence motifs are ubiquitous across the three major types of biomolecules: hundreds of classes and thousands of instances of DNA regulatory elements, RNA motifs and protein short linear motifs (SLiMs) have been characterised. The increase in complexity of transcriptional, post-transcriptional and post-translational regulation in higher Eukaryotes has coincided with a significant expansion of motif use. But how did the eukaryotic cell acquire such a vast repertoire of motifs? In this review, we curate the available literature on protein motif evolution and discuss the evidence that suggests SLiMs can be acquired by mutations, insertions and deletions in disordered regions. We propose a mechanism of ex nihilo SLiM evolution - the evolution of a novel SLiM from "nothing" adding a functional module to a previously non-functional region of protein sequence. In our model, hundreds of motif-binding domains in higher eukaryotic proteins connect simple motif specificities with useful functions to create a large functional motif space. Accessible peptides that match the specificity of these motif-binding domains are continuously created and destroyed by mutations in rapidly evolving disordered regions, creating a dynamic supply of new interactions that may have advantageous phenotypic novelty. This provides a reservoir of diversity to modify existing interaction networks. Evolutionary pressures will act on these motifs to retain beneficial instances. However, most will be lost on an evolutionary timescale as negative selection and genetic drift act on deleterious and neutral motifs respectively. In light of the parallels between the presented model and the evolution of motifs in the regulatory segments of genes and (pre-)mRNAs, we suggest our understanding of regulatory networks would benefit from the creation of a shared model describing the evolution of transcriptional, post-transcriptional and post-translational regulation.
\end{abstract}

Keywords: Motifs, Short linear motifs, SLiMs, Cis-regulatory elements, RNA motifs, Evolution, Modularity, Protein evolution

\section{Background}

Over the past 20 years our understanding of genome organisation expanded rapidly as researchers leveraged breakthroughs in sequencing technology to determine the complete DNA sequence of numerous eukaryotic genomes. It quickly became clear that these genomes differed in several important ways from the prokaryotic genomes that preceded them. Perhaps the most obvious difference was that eukaryotic genomes contained a much larger proportion of non-coding DNA than their distant prokaryotic relatives. In the first decade of the $21^{\text {st }}$ century, the genomics community turned to

\footnotetext{
* Correspondence: norman.davey@ucd.ie

${ }^{1}$ Conway Institute of Biomolecular and Biomedical Sciences, University College Dublin, Dublin 4, Ireland

Full list of author information is available at the end of the article
}

identifying the complete repertoire of functional elements in these non-coding regions. This led to a flurry of research to understand the function and evolution of the human genome's vast "heart of darkness" [1], culminating with ENCODE and related projects [2-4]. Over the same period of time surprising discoveries were causing a similar transition in thinking about the protein products of the eukaryotic genomes [5, 6]. Structural studies were revealing that a substantial number of proteins or segments of proteins in complex organisms are intrinsically disordered, lacking a stable well-defined tertiary structure in their native state $[7,8]$. Moreover, these regions were shown to perform numerous functions - directly contradicting the structure-function paradigm, a basic tenet of structural biology [6, 9-11]. These observations, like the analogous discovery of the 
extensive functionality of non-coding regions, forced a paradigm shift and sparked an interest in these hitherto underappreciated regions.

Many of the interactions mediated by these regions were observed to be low-affinity. Consequently, they often mediate interactions where the biological requirements are such that a transient or dynamic binding event is preferable $[10,12]$. Unexpectedly, the vast majority of these modules were shown to be encoded in short regions, what we now describe as short linear motifs (or SLiMs), of less than ten amino acids that mediate transient interactions with peptide binding domains [13]. Furthermore, within these peptides, as few as three or four residues typically encoded the majority of affinity and specificity of binding [10, 14]. Despite these barriers to motif discovery the census of modules rapidly expanded and thousands of SLiMs have now been functionally characterised [9]. They are known to be involved in a diverse array of functions: they assist in protein complex assembly; recruit substrates to modifying enzymes; control protein stability; direct trafficking to and anchoring in specific subcellular locations; and act as sites of post-translational modification (PTM) moiety addition or removal, proteolytic cleavage and structural modification $[9,10,12,13]$. However, despite increasing appreciation of their abundance and importance [10, 15], little was known until recently about SLiM evolution: especially in comparison to globular domain evolution whose duplication, divergence and recombination was already textbook knowledge [16, 17]. Nevertheless, consideration of the potential evolutionary plasticity of the compact and degenerate SLiMs led to the hypothesis that they could play key roles in protein evolution [16]: acquiring a novel SLiM is an appealing mechanism whereby a protein can gain important regulatory functions. Therefore protein networks could acquire new interactions with only a few amino acid changes [16]. Indeed, short DNA regulatory motifs were thought to be key substrates for transcriptional regulatory evolution [18], and a parallel with protein motifs seemed possible [16].

In the past 10 years, there has been much progress in testing the hypothesis that the gain and loss of SLiMs can underlie evolutionary changes in protein function. Here, we review illustrative examples of SLiM evolution and large-scale efforts to characterise the evolutionary diversity of SLiMs. In doing so, we identify several outstanding questions about the origin and evolution of SLiMs: What are the evolutionary forces that drive motif evolution? What is the mechanism of motif binding pocket evolution? When did extensive motif use evolve? Finally, we discuss the parallels in motif evolution at the transcriptional, posttranscriptional and post-translational regulation level.

\section{The evolutionary properties of short linear motifs}

Historically, SLiMs were discovered as islands of conservation in rapidly evolving regions and, as a result, many of the early motif instances were conserved over large taxonomic ranges [19-22]. Consequently, it has long been clear that a substantial number of motifs with important functions are under strong purifying selection against deleterious mutations [23]. For example, the PCNA-binding PIP box motif in Flap endonuclease 1 (FEN1) is conserved across all Eukaryotes [24] and Archaea [25] surviving over three billion years of evolution (Fig. 1a). Furthermore, SLiMs recognised by the same motif-binding pocket are typically found in multiple non-homologous proteins (Fig. 1b-d). This led to the proposal of a mechanism of motif acquisition driven by ex nihilo motif birth by random mutation [16]. However, motif birth had not been directly observed. This posed a fundamental question about motif evolution - how common is ex nihilo motifs motif birth from random sequence? A pioneering study of patients with Noonan-like syndrome revealed that several patients have de novo S2- > G substitutions in human leucine-rich repeat protein SHOC-2 (SHOC2) that result in the ex nihilo birth of a myristoylation motif [26] (Fig. 2a). Remarkably, this mutation was shown to have occurred independently on multiple occasions and for all individuals where the parental sequence was tested the substitution was absent in the parents. These observations suggested that random mutation can drive ex nihilo motif birth and that alleles with novel motifs may be common in a population [26].

Over the past decade, several analyses tracing the taxonomic range of motifs have shown that SLiMs are regularly gained and lost by individual lineages (see Table 1 , Fig. 2a-f). A recent unbiased proteome-wide analysis of the calcineurin $(\mathrm{Ca} 2+/$ calmodulin-dependent phosphatase) binding PxIxIT docking motif in Saccharomyces cerevisiae revealed that approximately $70 \%$ of PxIxIT sites are limited to the Saccharomyces sensu stricto clade and therefore have evolved within the past 20 million years [27] (Fig. 2b). The extensive datasets provided by highthroughput proteomic studies corroborate these observations by repeatedly returning a large number of motifs that are clade specific $[28,29]$ and by revealing that SLiMmediated interactions are rapidly rewired compared to other classes of protein-protein interaction [30-33]. Interestingly, despite the evolutionary transience of individual motif instances, interaction networks are often conserved. Many yeast Cyclin-dependent kinase 1 (Cdk1) phosphorylation motifs are evolutionarily transient but the presence of a modification site(s) in a given protein region is conserved [29]. Similarly, the acidophilic caspase family cleavage site motifs are often lost in orthologous proteins, however, are gained in different members of a targeted pathway thereby conserving network functionality [34]. This process of motifs appearing and disappearing while 


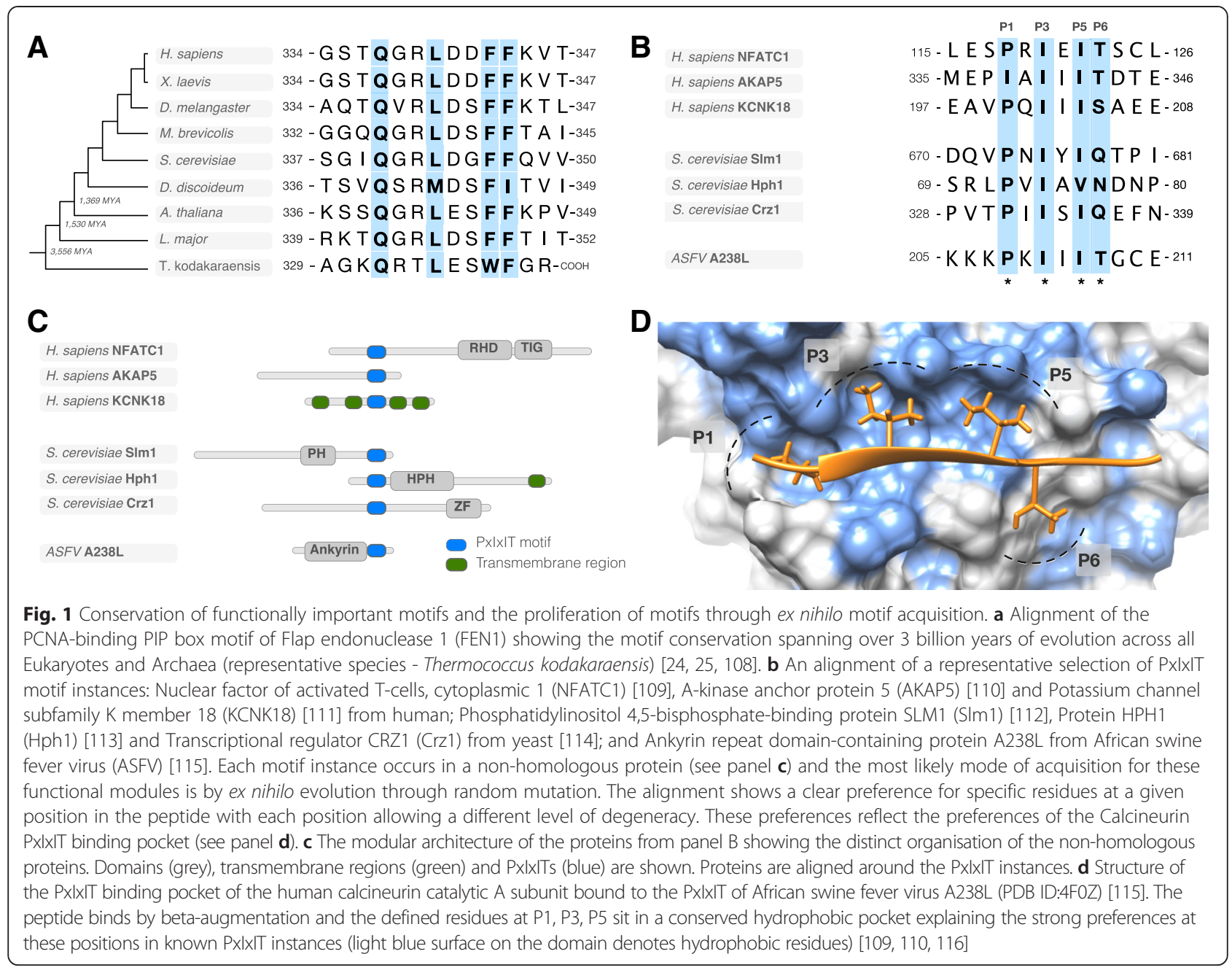

preserving the same interactions is sometimes referred to as "turnover" [35]. The development of distinct protein functionality either post-duplication or after de novo gene birth also provides insights into motif gain and loss [36] (see Table 1). Gene duplication often results in alteration of the transcriptional, posttranscriptional or post-translational control of the paralogues [37]. Many paralogous proteins acquire distinct functionality by gaining or losing SLiMs [38, 39] that result in differential regulation $[36,40]$ or subfunctionalisation [41, 42] (Fig. 2d-e). De novo gene birth, the gain of a novel transcribed and translated gene, has recently been revealed to be relatively common [43]. Currently, few proteins resulting from recent de novo gene birth have been functionally characterised, and examples of motif-containing novel proteins are even rarer. However, instances from HIV accessory proteins, considered to be products of de novo gene birth, suggest that motif acquisition may be a common route for a novel protein to gain functional modules [44-46] (see Table 1).
The degeneracy of motif-binding domain specificity provides substantial flexibility for a motif-containing peptide to encode a range of binding attributes. Consequently, evolution can adjust the affinity, specificity and selectivity of each domain-motif interaction in the network [10, 47-49]. For example, the affinities of PxIxIT docking motifs for calcineurin can range over two orders of magnitude [50]; artificially increasing the affinity of the PxIxIT motif in the calcineurin-activated transcriptional regulator CRZ1 (Crz1) results in constitutive dephosphorylation, transcriptional hyperactivity, and disruption of other calcineurin-dependent events [51]. This suggests that motif instances in the calcineurin substrate network may have been tuned to optimally regulate substrate modification state. Similarly, the affinity of a PxxP motif in the MAP kinase kinase PBS2 (Pbs2) for its target SRC Homology 3 (SH3) domain in yeast high osmolarity signaling protein $\mathrm{SHO}$ (Sho1) correlates linearly with the biological output of the high osmolarity glycerol pathway, suggesting that evolution tuned this response by optimising the strength of the interaction [52]. 


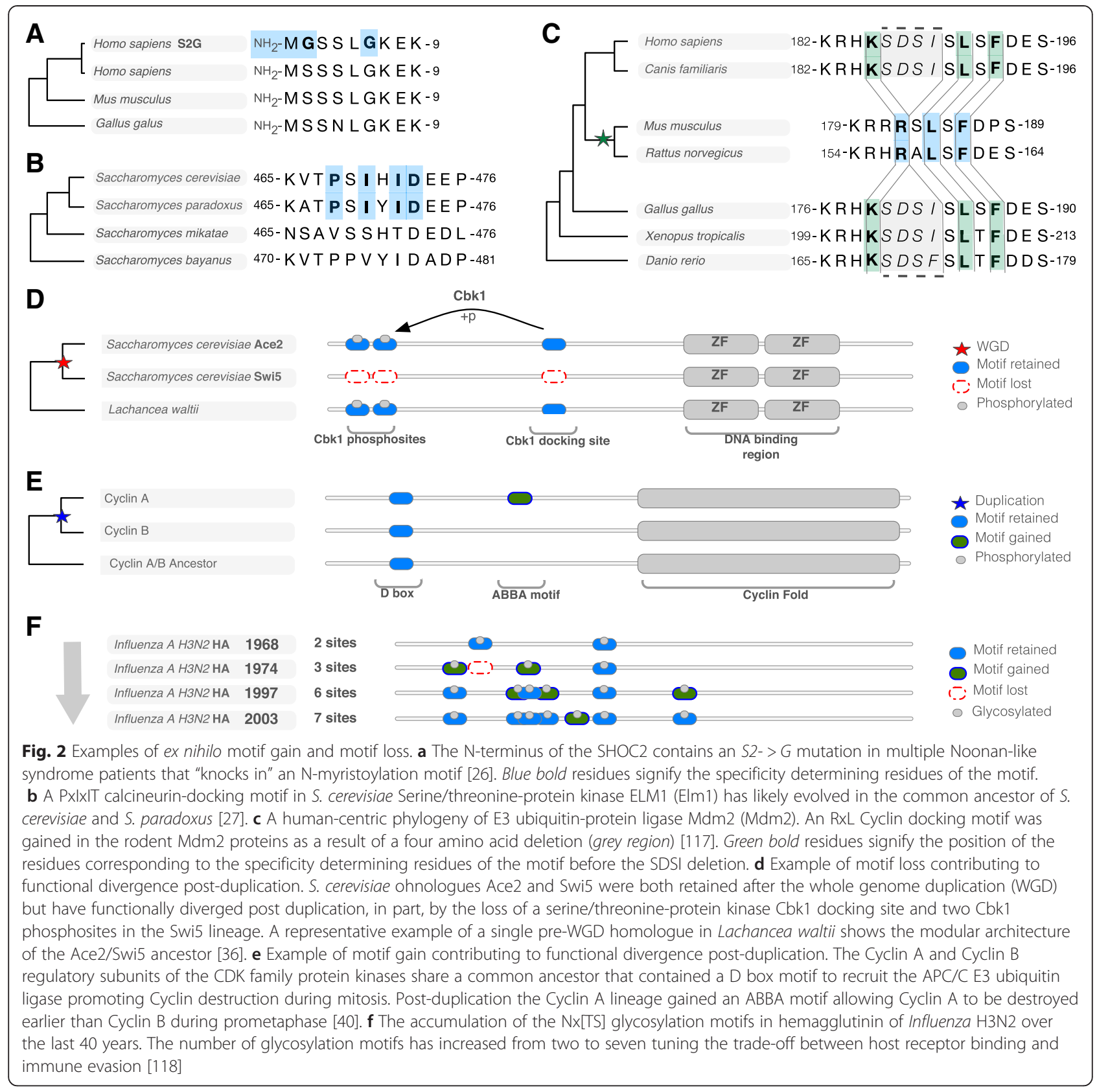

The same motif was shown to bind exclusively to the Sho1 SH3 domain in yeast, but to multiple non-yeast SH3 domains, indicating that evolution has tweaked the motif-domain interface to reduce deleterious promiscuous binding to other co-localised $\mathrm{SH} 3$ domains in the yeast proteome [53]. A further level of motif tuning occurs through the acquisition of additional, co-operative motifs (Fig. 2d-f) (see Table 1). For example, the addition of a cluster of $\mathrm{Cdk} 1$ consensus sites to the flanks of a pre-existing nuclear localisation signal (NLS) adds a novel level of regulation to the nucleocytoplasmic shuttling of DNA replication licensing factor MCM3 (Mcm3) in yeast [54]. Similar switching mechanisms involving co-operative and competitive use of motifs have evolved on numerous occasions [12, 27, 55, 56]. Remarkably, complete multi-motif interfaces can be acquired relatively rapidly on an evolutionary timescale, for example, the sequential recruitment of motif-binding partners to the multi-motif interfaces regulating the degradation of yeast Cell division control protein 6 (Cdc6) [57] and N-acetyltransferase ECO1 (Eco1) [58]. 
Table 1 Table of characterised examples of motif gain and loss modulating protein function

\begin{tabular}{|c|c|c|c|c|}
\hline Species protein (Gene) & Motif & Sequence $^{a}$ & Evolution & Function \\
\hline \multicolumn{5}{|l|}{ Ex nihilo motif acquisition } \\
\hline $\begin{array}{l}\text { H. sapiens Leucine-rich repeat } \\
\text { protein SHOC-2 (SHOC2) }\end{array}$ & $\begin{array}{l}\mathrm{N} \text {-myristoylation } \\
\text { motif }\end{array}$ & $\underline{\mathrm{MGSSLG}} 6$ & $\begin{array}{l}\text { Allele with a single S2-> G mutation in SHOC2 in Noonan-like } \\
\text { syndrome patients "knocks in" a motif [26]. }\end{array}$ & $\mathrm{N}$-myristoylation of $\mathrm{SHOC2}$ \\
\hline $\begin{array}{l}\text { H. sapiens Adapter molecule } \\
\text { crk (CRK) }\end{array}$ & $\begin{array}{l}\text { ABL1 SH3 } \\
\text { domain binding } \\
\text { motif }\end{array}$ & ${ }_{69} \mathrm{PPV} \underline{\mathbf{P}} \mathrm{PS} \underline{\mathbf{P}}_{\mathrm{AQP}}{ }_{78}$ & Ex nihilo acquisition in early mammals [85]. & Recruitment of ABL1 to CRK \\
\hline $\begin{array}{l}\text { S.cerevisiae Cell division control } \\
\text { protein } 6 \text { (Cdc6) }\end{array}$ & $\begin{array}{l}\text { SCF Cdc4 } \\
\text { degrons }\end{array}$ & ${ }_{364} \mathrm{QVP} \underline{\mathbf{L T P}} T \underline{\mathbf{S P V}} \mathrm{K}_{375}$ & Ex nihilo acquisition in Saccharomyces sensu stricto clade [57]. & $\begin{array}{l}\text { Degradation of Cdc6 by the SCF E3 } \\
\text { Ub ligase }\end{array}$ \\
\hline $\begin{array}{l}\text { M. musculus E3 ubiquitin-protein } \\
\text { ligase Mdm2 (Mdm2) }\end{array}$ & $\begin{array}{l}\text { Cyclin binding } \\
\text { motif }\end{array}$ & ${ }_{179} K_{K K R R} \underline{\mathbf{R}} \boldsymbol{L} \mathbf{S} \underline{\mathbf{F}} D P S_{189}$ & $\begin{array}{l}\text { Acquisition in the rodent lineage via a four amino acid deletion } \\
\text { [117]. }\end{array}$ & $\begin{array}{l}\text { Recruitment of and phosphorylation } \\
\text { by CDK2 }\end{array}$ \\
\hline $\begin{array}{l}\text { D. melanogaster Segmentation } \\
\text { polarity homeobox protein } \\
\text { engrailed (en) }\end{array}$ & $\begin{array}{l}\text { Groucho } \\
\text { interacting motif }\end{array}$ & ${ }_{198} \mathrm{QASIFRPF} E \mathrm{ES}_{208}$ & Ex nihilo acquisition in diptera/lepidoptera [134]. & Recruitment of groucho \\
\hline $\begin{array}{l}\text { S.cerevisiae Serine/threonine- } \\
\text { protein kinase ELM1 (Elm1) }\end{array}$ & $\begin{array}{l}\text { Calcineurin } \\
\text { docking motif }\end{array}$ & 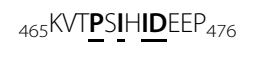 & Ex nihilo acquisition in Saccharomyces sensu stricto clade [27]. & $\begin{array}{l}\text { Recruitment of and dephosphorylation } \\
\text { by calcineurin }\end{array}$ \\
\hline Influenza hemagglutinin $(\mathrm{H} 3)$ & $\begin{array}{l}\mathrm{N} \text {-glycosylation } \\
\text { motifs }\end{array}$ & Five NxT sites & $\begin{array}{l}\text { Strains spanning the last } 40 \text { years have shown gradual acquisition } \\
\text { of five novel N-glycosylation sites [118]. }\end{array}$ & $\begin{array}{l}\text { Increased immune system evasion and } \\
\text { decreased infectivity }\end{array}$ \\
\hline \multicolumn{5}{|l|}{ Motif gain/loss post duplication } \\
\hline $\begin{array}{l}\text { S. cerevisiae Spindle assembly } \\
\text { checkpoint component MAD3 } \\
\text { (Mad3) }\end{array}$ & $\begin{array}{l}\text { APC/C Cdc20 } \\
\text { binding KEN box }\end{array}$ & ${ }_{27} \mathrm{ETQKEN} \mathrm{LP} \mathrm{P}_{35}$ & $\begin{array}{l}\text { Lost in the Bub1 functional homologues after Mad3-like/Bub1-like } \\
\text { duplications [41]. }\end{array}$ & Loss of APC/C inhibitory function \\
\hline $\begin{array}{l}\text { S. cerevisiae Metallothionein } \\
\text { expression activator (Ace2) }\end{array}$ & $\begin{array}{l}\text { Cbk1 docking } \\
\text { motif }\end{array}$ & ${ }_{280}{ }^{N G G Y Q} \underline{\text { FPPPPTL }} 291$ & Lost in Swi5 after Swi5/Ace2 duplication [36]. & Loss of Cbk1 regulated localisation \\
\hline H. sapiens Cyclin-A2 (CCNA2) & $\begin{array}{l}\text { APC/C CDC20 } \\
\text { binding ABBA } \\
\text { motif }\end{array}$ & ${ }_{96} \mathrm{QPAF} \underline{\mathrm{TIH}} \underline{\mathrm{D}} \underline{E A E_{108}}$ & $\begin{array}{l}\text { Ex nihilo acquisition in Cyclin A after the Cyclin A/Cyclin B } \\
\text { duplication [40]. }\end{array}$ & $\begin{array}{l}\text { Early degradation during an active } \\
\text { spindle assembly checkpoint }\end{array}$ \\
\hline \multicolumn{5}{|l|}{ Tuning of motif specificity/affinity } \\
\hline $\begin{array}{l}\text { S. cerevisiae MAP kinase kinase } \\
\text { Pbs2 (Pbs2) }\end{array}$ & $\begin{array}{l}\text { Sho1 SH3 } \\
\text { domain binding } \\
\text { motif }\end{array}$ & 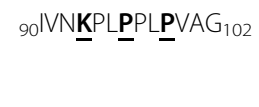 & $\begin{array}{l}\text { Only binds the } \mathrm{SH} 3 \text { domain of yeast Sho } 1 \text { but can be recognised by } \\
\text { multiple non-yeast } \mathrm{SH} 3 \text { domains [53]. }\end{array}$ & Specific interaction with Sho1 \\
\hline $\begin{array}{l}\text { S. cerevisiae Peroxisomal } \\
\text { membrane protein PEX14 } \\
\text { (Pex14) }\end{array}$ & $\begin{array}{l}\text { Pex14 SH3 } \\
\text { domain binding } \\
\text { motif }\end{array}$ & ${ }_{84} \mathrm{AMP} \underline{\mathbf{P}}-\underline{\mathbf{P}} \underline{\mathrm{H}} \underline{\mathbf{R}} \mathrm{D}_{93}$ & $\begin{array}{l}\text { Promiscuous in vitro but only binds the SH3 domain of co-localised } \\
\text { Pex13 in vivo [53]. }\end{array}$ & Promiscuous in vitro interactions \\
\hline \multicolumn{5}{|c|}{ Ex nihilo co-operative/competitive interface evolution } \\
\hline \multirow[t]{2}{*}{$\begin{array}{l}\text { S. cerevisiae N-acetyltransferase } \\
\text { ECO1 (ECO1) }\end{array}$} & $\begin{array}{l}\text { SCF Cdc4 } \\
\text { degron }\end{array}$ & ${ }_{90}$ TGTITPLNS $\underline{\mathbf{S}} \mathrm{PL}_{101}$ & $\begin{array}{l}\text { Ex nihilo acquisition in the Saccharomycetaceae clade of four motifs } \\
\text { required for sequential kinase and ubiquitin ligase recruitment [58]. }\end{array}$ & $\begin{array}{l}\text { Degradation of ECO } 1 \text { by the SCF E3 } \\
\text { Ub ligase }\end{array}$ \\
\hline & $\begin{array}{l}\text { Mck1 } \\
\text { modification site }\end{array}$ & ${ }_{91} \mathrm{GTI} \underline{\mathrm{T}} \mathrm{PLN} \underline{\mathrm{S}} \mathrm{SPL}_{101}$ & & \\
\hline
\end{tabular}


Table 1 Table of characterised examples of motif gain and loss modulating protein function (Continued)

\begin{tabular}{|c|c|c|c|c|}
\hline & $\begin{array}{l}\text { Cdc7 } \\
\text { modification site }\end{array}$ & ${ }_{95} \mathrm{PLN} \underline{\mathbf{S S}} \mathrm{PLKK}{ }_{103}$ & & \\
\hline & $\begin{array}{l}\text { Cdk1 } \\
\text { modification site }\end{array}$ & ${ }_{96} \mathrm{LNS} \underline{\mathbf{S P}} \underline{\mathrm{LKKSS}}{ }_{105}$ & & \\
\hline \multirow[t]{2}{*}{$\begin{array}{l}\text { S. cerevisiae DNA replication } \\
\text { licensing factor MCM3 (Mcm3) }\end{array}$} & $\begin{array}{l}\text { Cdk1 } \\
\text { modification } \\
\text { sites }\end{array}$ & ${ }_{758} \mathrm{SKR} \underline{\mathbf{S P}} \underline{\mathbf{K}} \mathrm{SPK}_{767}$ & $\begin{array}{l}\text { Ex nihilo acquisition of a cluster of Cdk1 modification sites in the } \\
\text { Saccharomycetaceae family [54]. }\end{array}$ & $\begin{array}{l}\text { Regulation of nucleocytoplasmic } \\
\text { shuttling of } \mathrm{Mcm} 3\end{array}$ \\
\hline & & ${ }_{762} \mathrm{PQKS}_{\underline{\mathbf{S P}}} \underline{\mathbf{K}} \boldsymbol{R Q R}{ }_{771}$ & & \\
\hline \multirow[t]{2}{*}{ S. cerevisiae DIG2 (Dig2) } & MAPK D-site & ${ }_{97} \mathrm{HSL} \underline{\text { KRKRVVPPALNFFSDI }}{ }_{113}$ & \multirow{2}{*}{$\begin{array}{l}\text { Acquisition of MAPK D-site followed by ex nihilo acquisition of } \\
\text { overlapping calcineurin-binding Px|x|T site; Dig1 paralog contains } \\
\text { D-site but no PxIXIT [27, 135]. }\end{array}$} & \multirow{2}{*}{$\begin{array}{l}\text { Competitive recognition of substrate } \\
\text { by kinase and phosphatase }\end{array}$} \\
\hline & $\begin{array}{l}\text { Calcineurin } \\
\text { Px|x|T }\end{array}$ & ${ }_{103} \mathrm{RVP} \underline{\mathbf{P}} \underline{\mathrm{ALN}} \underline{\mathrm{FS}} \mid \mathrm{Q} \mathrm{A}_{114}$ & & \\
\hline \multirow[t]{2}{*}{$\begin{array}{l}\text { H. sapiens Retinoblastoma- } \\
\text { associated protein RB (RB1) }\end{array}$} & $\begin{array}{l}\text { Cyclin A } \\
\text { docking site }\end{array}$ & ${ }_{873} \underline{\mathbf{K}} \underline{K} \underline{\underline{L}} \underline{\mathbf{F}} \underline{\mathbf{F}}_{875}$ & \multirow[t]{2}{*}{ Co-evolution of PP1 and Cyclin A recognition motifs $[56,136]$. } & \multirow[t]{2}{*}{$\begin{array}{l}\text { Competitive recognition of substrate } \\
\text { by kinase and phosphatase }\end{array}$} \\
\hline & $\begin{array}{l}\text { PP1 binding } \\
\text { RVxF }\end{array}$ & ${ }_{873} \underline{K L L R F}_{877}$ & & \\
\hline \multicolumn{5}{|l|}{ Motif gain/loss post de novo gene birth } \\
\hline $\begin{array}{l}\text { Human immunodeficiency virus type } 1 \\
\text { (HIV-1) Protein Vpu (vpu) }\end{array}$ & $\begin{array}{l}\text { SCF } \beta-\operatorname{TrCP} \\
\text { degron }\end{array}$ & ${ }_{48} \mathrm{RAEDSGNES} \mathrm{EGE}_{59}$ & $\begin{array}{l}\text { Ex nihilo acquisition in the novel overprinted Vpu protein, present } \\
\text { only HIV-1 and its simian precursors }[44,45] \text {. }\end{array}$ & $\begin{array}{l}\text { Highjacking of the host SCF- } \beta \text {-TrCP E3 } \\
\text { Ub ligase }\end{array}$ \\
\hline
\end{tabular}

Sequence overlapping motif - the major specificity and affinity determining residues of the motif are underlined and in bold 


\section{What are the evolutionary forces that drive specific motif evolution? \\ Ex nihilo motif birth}

In contrast to protein domain evolution - which is driven by duplication, recombination and divergence $[59,60]$ we still lack a clear understanding of the mechanisms driving SLiM evolution. To understand the mechanism of ex nihilo motif birth we must consider two major observations about SLiMs: (i) like the analogous motifs in the regulatory regions of DNA and (pre-)mRNA, they are compact and degenerate [13] (Fig. 3a-c); and (ii) they usually occur in rapidly evolving intrinsically disordered regions $[13,61,62]$. The majority of SLiM-binding domains have weak specificity, because they contact a core motif of only three to four residues, and often tolerate amino acids in these positions that have similar physicochemical properties [13]. Similarly, there are few restrictions on the amino acids that flank the motif, although these residues can indirectly modulate the physical, chemical or structural compatibility of the peptide with the target domain (Fig. 1d) [10, 13, 14, 63]. Consequently, the motif core is necessary but not sufficient for binding and many bone-fide motif instances fail to conform to the consensus sequence. Given these limited specificity and affinity determinants of the motif, they are expected to occur frequently by chance (Fig. 3d) [13], and a proteome will contain many peptides that are complementary to the motif-binding pocket (though many of these sequences will never meet their binding partner in the cell due to temporal and spatial restrictions [64]). Because much of the intrinsically disordered regions of a proteome are apparently under weak selective constraints and are rapidly changing at the sequence level [61], mutations, insertions and deletions in these regions facilitate the rapid sampling of sequence space. Taken together, the simplicity of the motif and the rapid evolution of disordered regions drive a system where peptides complementary to the binding pocket of a given SLiM-binding domain are rapidly being created, by ex nihilo motif birth, and destroyed. This everchanging set of motifs may represent a dynamic evolutionary reservoir of new protein-protein interactions that fuel selectable phenotypic diversity.

\section{Motif fixation}

Motif birth occurs as a single mutation in a single allele in a single member of a species. When studying motifs, we generally consider a motif present in a fixed allele (i.e. it is present in all members of the population SLiM-containing alleles may also be subject to balancing selection though no examples are known). On a population level, the steps from the ex nihilo birth of a motif to fixation or loss can follow several paths (Fig. 3e). The likelihood of motif fixation or loss will be dependent on the phenotype of the motif and the effective population size [65]. For clarity three basic groupings can be used to describe a continuum of motif phenotypes: beneficial motifs are those that have an adaptive phenotype; neutral motifs are those that do not have any selectable positive or negative phenotype; and deleterious motifs are those that have a selectable negative phenotype. As a general model, alleles with beneficial motifs will be under positive selection and will become fixed in the population; those with neutral motifs can become fixed or lost by genetic drift; and those with deleterious motifs will be lost by negative selection. However, due to stochasticity in the evolutionary process, exceptions will occur. For example, beneficial motifs can be lost by genetic drift before they reach appreciable frequencies and deleterious motifs can become fixed in small populations. Once a motif has become fixed, negative (or purifying) selection will retain beneficial motifs, and subsequent mutations that become fixed by genetic drift will tend to remove neutral motifs over time. Substitutions that deleteriously affect the affinity, specificity and selectivity of a beneficial motif will generally be under negative selection and will fail to spread through the population. Conversely, those that result in a superior phenotype will be under positive selection and can become fixed. The interplay of this positive and negative selection might give directionality to the evolution of a motif and could in effect act as a ratchet to optimise the motif's binding attributes (Fig. 3f).

\section{Motif optimization in a network}

Multiple motif-containing proteins are often competing for a finite pool of a given motif-binding pocket-containing protein. The optimisation of each motif must thus be considered in the context of the whole interaction network: to balance competition between motif-containing proteins and define the proportion of each motif-containing protein that occupies a given motif-binding pocket. These systems must consider the timing/strength of expression of the motif-containing and motif-binding partners and, as many motifs function in multiprotein complexes and cannot sustain interactions without co-operativity, changes in expression of scaffolding molecules. Such a model would require co-evolution of the network to tune the attributes of each interface in reaction to changes to the network. These network changes can include: an increase or decrease in the abundance of a component of the network; the gain or loss of a motif; mutations that alter the affinity, specificity and selectivity of a motif; or the addition of intramolecular cooperativity between motifs that can increase the avidity of an interaction, increase the specificity of an interaction, or add regulatory constraints that act as conditional modulators of an interaction $[51,66]$. Many inhibitors of motifmediated systems, both endogenous and pathogenic, take advantage of the delicate balance of these systems by utilising high affinity motifs, or high avidity co-operative multi- 
A

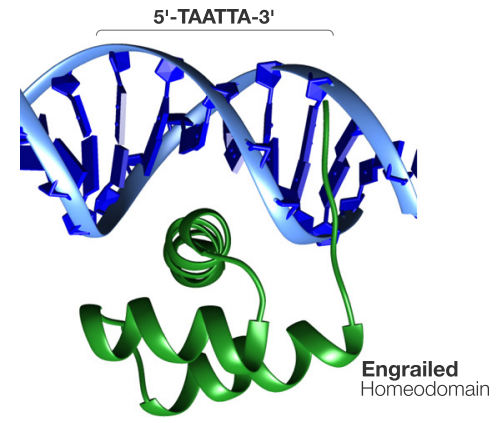

B

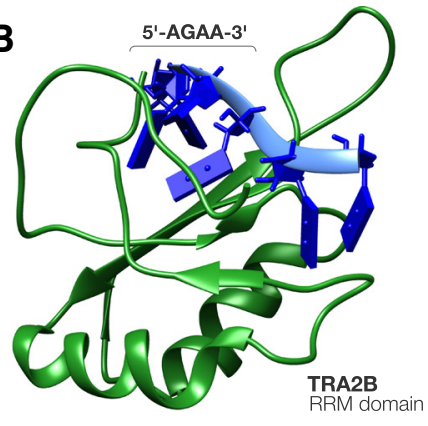

C

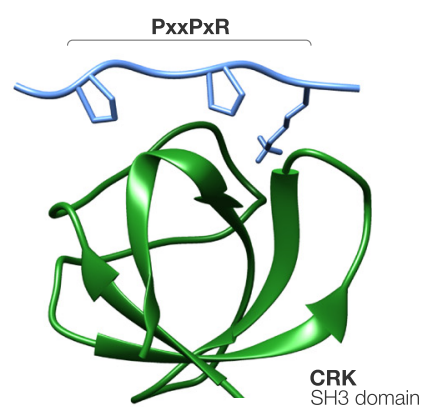

D

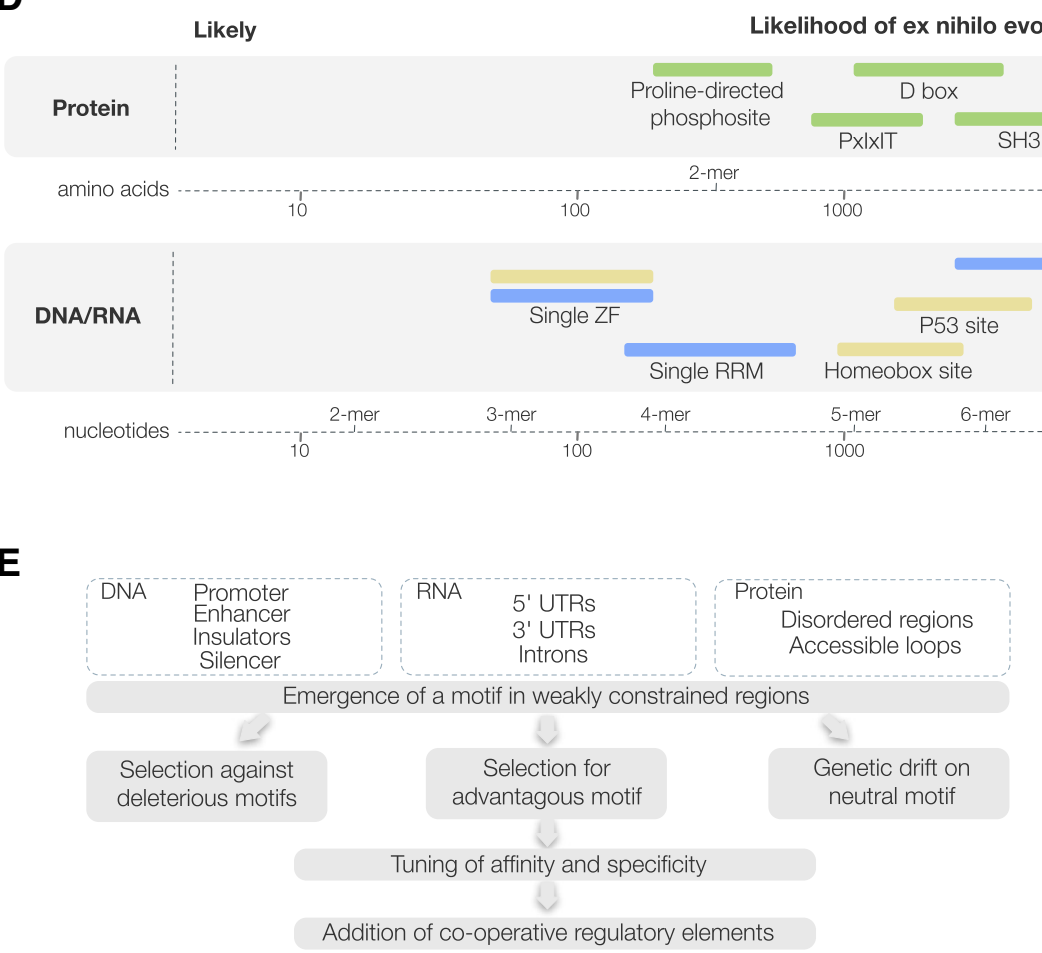

$\mathbf{F}$

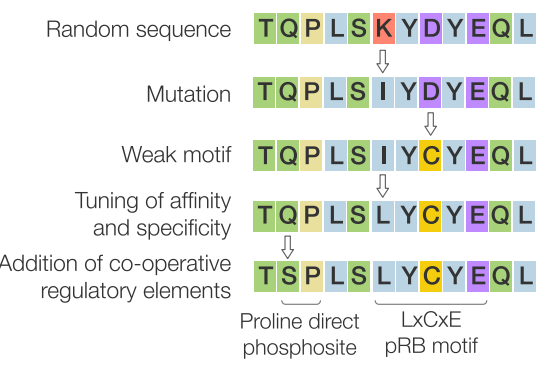

Fig. 3 The relationship between compact degenerate motifs, occurrence likelihoods and ex nihilo evolution. a The homeodomain of Drosophila Segmentation polarity homeobox protein engrailed (en) bound to a TAATTA subsite [119]. $\mathbf{b}$ The RRM of Transformer-2 protein homolog beta (TRA2B) bound to an AGAA exonic splicing enhancer (ESE) motif [120]. c The SH3 domain of Adapter molecule crk (CRK) bound to a PxxP motif from Rap guanine nucleotide exchange factor 1 (RAPGEF1) [121]. $\mathbf{d}$ The number of nucleotides or residues expected between instances of a motif occurring by chance in a sequence. A non-degenerate $x$-mer nucleotide motif instance would be expected to occur once every $4^{x}$ nucleotides (e.g. a 6-mer every $4^{6}$ or 4,096 nucleotides) and an non-degenerate $x$-mer protein motif would be expected to occur once every $20^{x}$ amino acids (e.g. a 3-mer peptide motif every $20^{3}$ or 8000 amino acids). The disparity in the length of the regions that contain these motifs (DNA, (pre-)mRNA and proteins) means that the number of random instances will vary by several fold across the three classes of biomolecule. Ranges are illustrative and are therefore approximate, based on over predictive consensuses (see motifs below) and use equal nucleotide (1/4) and amino acid (1/20) frequencies. Protein SLiMs: proline-directed phosphosite ([ST]P) [29]; D box degron (RxxLxx[ILMVK]) [69]; PxIxIT Calcineurin docking motif (Px[IVLF]x[IVLF][TSHEDQNKR]) [27]; SH3 domain-binding motif (PxxPx[KR]) [32]; PTAP late domain motif (P[TS]AP) [122]; and Fbw7 SCF degron([ILMVP]TPxx[ST]) [123]. RNA motif: A single RRM binding site (4 nucleotides) [124]; a single Zinc Finger recognition site (3 nucleotides) [125]; and an miRNA seed regions (6-8 nucleotides) [126]. DNA motifs: a single Zinc Finger recognition site (3 nucleotides) [127]; Homeobox domain (TAAT[GT][GT]) [128]; CAAT box ([TC]GATTGGTC]TTC][AG]) [129]; and P53 regulatory element (C[AT][AT]GNNNNNNC[AT][AT]G) [130]. e Simple model for motif acquisition by DNA, RNA and proteins (see text for details of model). f Potential mechanism of ex nihilo motif evolution illustrated using a hypothetical LXCXE pRB-binding motif (see text for details of model)

motif interfaces, to titrate the available motif-binding proteins $[46,67-69]$. A related question is whether the cumulative effect of all presumably individually neutral motifs on the network level can have an appreciable phenotype by titrating the motif-binding partner away from motifcontaining proteins. A consequence of this would be that there exists an upper limit to the number of instances of a motif in a proteome. It is evident that large numbers of 
motif instances for a single motif-binding partner are possible, for example, NLS motifs are present in hundreds of proteins yet they function without issue [70]. However, it has also been shown that motif-containing peptides in high concentrations can act as potent inhibitors [71]. Similar inhibitory effects have been observed for motifs with artificially increased affinities [51]. Several motif networks have been shown to recruit targets with a hierarchy driven by the intrinsic affinity for their motif-containing binding partner. In some cases, these networks regulate recruitment using competitive mechanisms facilitated by limiting amounts of the motif-binding domains [72]. So can evolutionarily neutral motif instances in sufficiently high quantities or with sufficiently high affinities act as inhibitors? Or would the set of novel untuned, and therefore possibly lower affinity, motifs be outcompeted by the key biological targets? This is currently unclear. However, the upper limit of instances of a functionally important motif is likely correlated with the abundance of the motif-binding protein and the abundance and relative affinities of the motifcontaining proteins. An important consideration is that motif-binding domains instances, in excess, can significantly bind a pool of weaker motifs beyond their normal targets [66]. Perhaps the expansion of a motif network is the result of an increase in the abundance of the motifbinding partner, and thus an expansion of the number of recruited motif-containing proteins, followed by a wave of selection. These concepts illustrate that when considering the evolutionary forces of mutations in motifs it is important to consider both protein autonomous effects (i.e., changes in the regulation of that protein) and effects due to modulation of the larger protein interaction network.

\section{What is the mechanism of motif-binding pocket evolution?}

Where do motif-binding pockets come from in the first place? A potential model of motif-binding pocket gain is that coevolution of the original binding partner(s) and the binding pocket optimises a surface for motif binding and, subsequently, additional peptides utilise the pocket to recruit the protein. The outcome of the reuse of the binding pocket by multiple distinct binding partners and the required complementarity between binding peptide and the binding pocket results in the repeated patterns that we refer to as motifs. Motif pocket birth has been observed for many domain families (e.g. the RNA recognition motif domain (RRM) and the WD40 repeat) where a family member acquires a novel motif-binding pocket (Fig. 4a) [73, 74]. A recent study presented structural and functional evidence for a derived dockingmotif binding-pocket in the highly conserved kinase domain of yeast serine/threonine-protein kinase CBK1 (Cbk1) [75]. In this case, after evolution of the binding pocket, docking motifs appear to have arisen ex nihilo in disordered regions of proteins that were already Cbk 1 substrates, and were subsequently preserved over evolution. Thus, fungal Cbk1 offers a rare example where the evolution of an entire SLiM-pocket interaction network has been traced. Once established, a SLiM binding pocket is generally conserved over large evolutionary distances as the motif partners constrain the pocket (unless the domain duplicates). For example, the NLS of human Myc proto-oncogene protein (MYC) can be recognised by importin subunit alpha (Srp1) of the yeast nuclear import machinery [76]. Conversely, co-evolution can also maintain critical binding interactions as the peptide binding domain specificity changes. This process of domain-motif co-evolution, where the motif recognised by a binding pocket and the binding pocket drift on the sequence level, has been observed in a few cases, such as the PCNA-binding PIP boxes [77] and the APC/C activator protein CDC20-binding ABBA motif $[40,78]$ in the fungal lineage.

Some motif-binding domains are members of large domain families. Members of most of these motif-binding domain families, while utilising the same binding pocket, have diverged specificities to recognise distinct, often overlapping, sets of peptides (Fig. 4b) [10, 75, 79, 80]. For example, the optimal specificities of kinases [81-83] and SRC Homology 2 (SH2) domains [84, 85] have diversified during family expansions. The specificity of a motif-binding pocket is dependent on its physicochemical properties. Evolutionary refinement of the domain surface post-duplication can modulate these physicochemical properties and thus the binding preferences of the motif-binding domain. For example, dependent on the biological requirement, amino acid changes in the binding surfaces can shift the binding preferences to allow a given peptide bind to one of the duplicated domains but not the other, or less drastically, bind with different affinities to each domain. Both mechanisms result in diverged specificities for the novel binding domains and over time the specificity of the domains can drift extensively. When overlapping specificity with homologous, or non-homologous, co-localised domains results in deleterious motif-binding events the specificities of motif-binding pockets will evolve to reduce this overlap $[48,53,83,86]$. For example, mitotic kinases have been observed to target the correct substrates by a combination of substrate co-localisation and kinase specificity. The specificity of several of these kinases have evolved to specifically disfavour the motifs of other co-localised mitotic kinases [48, 87].

\section{When did extensive motif use evolve?}

The diversity of the physicochemical properties of SLiMs is remarkable and it seems the only limit on the evolution of novel and distinct motif classes may be that the 


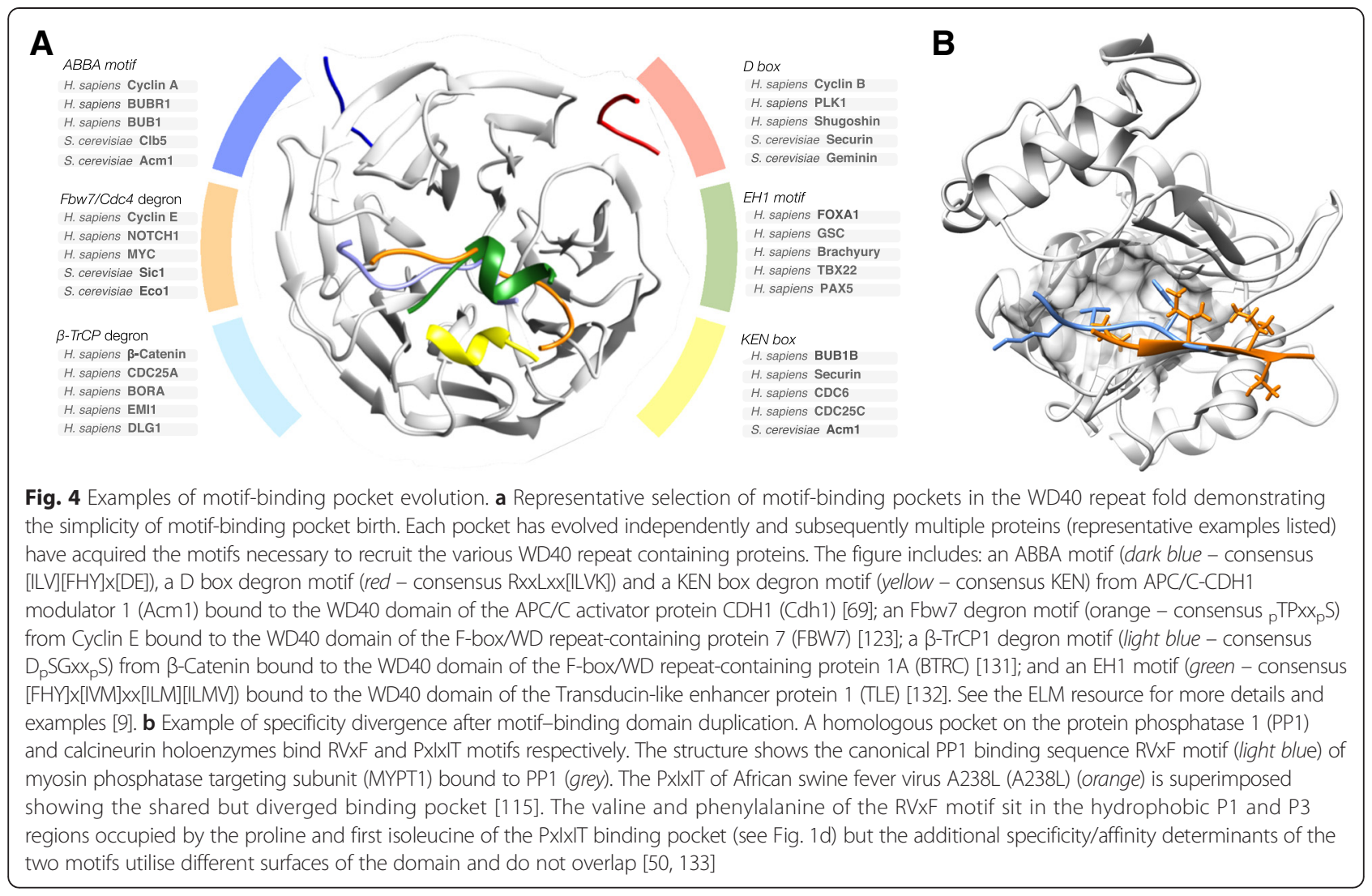

reuse of currently available motif-binding domains and the subtle tweaking of their specificity is sufficient in most cases. Nevertheless, when required evolution can and does innovate, however, often that innovation can use similar building blocks [73, 74]. A significant portion of the higher eukaryotic motif space (the set of motifs with the ability to specifically bind a SLiM-binding pocket) is now utilised by SLiM-binding domain families $[9,88-90]$. However, the exact timing of the explosion of SLiM use is unknown. Archaea and Bacteria use motifs, for example the sliding clamp binding motif [91] and several motifs in the degradosome protein Rnase $\mathrm{E}$ [92], but not to the same extent as Eukaryotes. Interestingly, this is reflected in the relative levels of intrinsic disorder in these domains of life [93], however, this relationship between the expansion of motif use and intrinsic disorder is still unstudied. The sporadic evolution of novel motif-binding pockets in domains that previously had no SLiM-binding ability has contributed to the diversity of SLiM-binding [73, 74]. However, much of the growth of motif space coincided with the expansion of the large canonical motif-binding domain (e.g. SH3) and motif-modifying domain (e.g. kinase) families in Eukaryotes (Table 2). An expansion that mirrors that of the canonical DNA and RNA motif-binding families. A common theme for these families is the duplication of a domain followed by the divergence of the specificity of the resulting domains. This has resulted in a complex landscape of specificities for many of the large motifbinding families in higher Eukaryotes [10]. Because most of these domain families were present in distantly related Eukaryotes, and many rapidly expanded thereafter, the general consensus is that extensive motif usage evolved very early in eukaryotic evolution $[85,94]$ and the diversity of motif types has continued to expand with the diversification of the motif-binding and motif-modifying

Table 2 Table of several classical SLiM-binding domain families, and representative DNA and RNA motif-binding domain families $^{a}$

\begin{tabular}{lllllll}
\hline Domain type & Domain & Ath & Ddi & Sce & Dme & Hsa \\
\hline SLiM-binding & SH3 domain & 5 & 29 & 23 & 59 & 204 \\
& PDZ domain & 17 & 1 & 2 & 67 & 145 \\
& SH2 domain & 2 & 13 & 0 & 32 & 110 \\
& WW domain & 9 & 5 & 6 & 21 & 41 \\
& Kinase domain & 1066 & 309 & 132 & 289 & 523 \\
DNA-binding & C2H2/C2HC zinc finger & 22 & 6 & 34 & 197 & 659 \\
RNA-binding & RRM domain & 268 & 96 & 58 & 137 & 265 \\
\hline
\end{tabular}

${ }^{\mathrm{a}}$ The number of instances of each family in Arabidopsis thaliana (Ath), Dictyostelium discoideum (Ddi), Saccharomyces cerevisiae (Sce), Drosophila melanogaster (Dme), Homo sapiens (Hsa). Data from Vogel et al. [95] 
domains [83, 85, 95]. Expansions of a given motifbinding domain family may also be specific to certain lineages $[95,96]$. For example, the motif-binding SH2 and SH3 domains, key metazoan signalling components, are rare in plant proteomes [95].

\section{Do common principles of regulatory evolution unite motifs in DNA, RNA and Protein?}

Many parallels have been observed for motif use at the transcriptional, post-transcriptional and post-translational level. For example, specification of responses through the co-operative action of multiple motif recruited regulators is a theme at all levels of regulation (transcription: [97], splicing: [98], miRNA [99], signalling [11]). Much like combinations of SLiMs in disordered regions that lead to combinatorial post-translational regulatory switches [55], enhancers integrate complex transcriptional circuitry to individual genes [97]. Like the regulatory regions of DNA and (pre-)mRNA, disordered regions containing multiple SLiMs are key foci where the gain and loss of motifs can lead to complex changes in cell regulation and physiology $[38,68]$. Another example is the analogy of SLiM-binding pocket and SLiM co-evolution with DNA-binding domain - DNA regulatory element co-evolution. Because of the predicted pleiotropy of DNA-binding domain specificity changes, it was argued that such changes (in trans) should be comparatively rare relative to changes in the modular DNA binding sites (in cis [18]). Nevertheless, several examples of such changes and the corresponding coevolution of DNA binding sites were subsequently identified (e.g., [100]). Once again, examples of pocketSLiM co-evolution exist [40, 77, 78]. Finally, recent genome-scale chromatin immunoprecipitation and DNase hypersensitivity mapping experiments have indicated that DNA-protein interactions evolve rapidly between species. These results suggest that many DNA motif - protein interactions in complex genomes are not preserved over evolution while a small subset of functional binding sites is preserved near key target genes [101]. This is analogous to the evolutionary reservoir model described above, where most SLiMs are evolutionarily transient, and a few core SLiMs are preserved by natural selection. The rapid evolutionary turnover of a large fraction of regulatory interactions is consistent with a model where most of the changes are nearly neutral with respect to selection $[65,102]$ (although we note that extensive lineage-specific selection could also produce similar patterns [103]). If the mostly neutral model is correct, only a small fraction of the evolutionary reservoir created by non-adaptive processes will be preserved by natural selection. Due to the size and complexity of eukaryotic genomes and proteomes and the short, degenerate nature of motifs, the rate of ex nihilo motif gain may be rapid enough that a large number of neutral regulatory interactions are present at all levels (DNA, RNA and proteins).

\section{Conclusion}

Every motif will be subjected to unique evolutionary pressures and novel motifs will fall along a phenotypic continuum rather than a neatly classifiable trinity of positive, neutral or negative phenotypes. Nevertheless, we have described a general model for the mechanism of motif evolution where the dynamic equilibrium of motifs being rapidly created ex nihilo in disordered regions and then destroyed by mutations provides a reservoir of functional diversity in protein interaction networks. We believe this diversity represents a key raw material exploited by evolution as it elaborates the complexity of the cell. This advocates a model of protein evolution resulting from both domain duplication and ex nihilo motif evolution.

The expansion of motif-binding domains linking compact and degenerate peptides to important functions greatly increased the information processing potential of the cell by simplifying access to regulatory pathways and cell state information. This expansion of functional motif space has allowed mutations, insertions and deletions to act as a powerful mechanism to add novel functional modules to a protein. Such a simple evolutionary mechanism to create selectable phenotypic diversity appears to have been advantageous to many organisms as it was extensively expanded and exploited resulting in an explosion in network connectivity and an increase in the regulatory complexity of the cell. The large functional motif space also increased the evolvability of these organisms by offering huge potential future adaptive evolution. Thus, it is tempting to assume that increasing motif usage is beneficial to complex organisms. However, as the Noonan-like syndrome motif "knock in" example shows, on an individual level, the deleterious effect of motif birth can be severe. The relative likelihood of motif gain and loss is still unknown, however, it is possible that if the effective population size becomes small for complex organisms, and interactions may appear ex nihilo in disordered regions at a high enough rate, natural selection might simply not be strong enough to purge them. $[65,104]$.

Many basic questions remain regarding the extent of motif use. How many motifs specifically bind each motif-binding pocket? How many of these motif-binding events are biologically important? How many are "evolutionary noise" [65]? These unknowns complicate our quest to understand motif evolution and consequently numerous unanswered evolutionary questions also exist. How often do motifs arise ex nihilo? What proportion of these novel motifs are advantageous, deleterious and neutral? What is the cumulative cost of multiple neutral 
motifs? If the acquisition of a given motif class is advantageous to a particular protein will it eventually acquire it? How does evolution optimise the binding attributes of a motif? How do co-operative sets of motifs evolve (Does the presence of a motif increase the likelihood of the acquisition of a co-operative motif)? Further experimental and theoretical exploration is needed to answer these questions. This will be confounded by experimental limitations (perhaps "biologically irrelevant" motifs haven't been tested under the correct lab conditions) and the weak phenotypes, redundancy and cooperativity of many motifs. This remains a key area of research and will require numerous experimental and analytical advances. A key step will be the creation of unbiased, proteome-wide approaches to identify SLiMs, such as proteomic phage display $[105,106]$. Although the experimental and analytical techniques will be specific to SLiMs, in light of the parallels between regulatory motifs in all the major macromolecules, we suggest that studies aimed at understanding the mechanisms of SLiM evolution should consider their evolutionarily analogous motifs in the regulatory regions of DNA and (pre-)mRNA. Ultimately, our understanding of cell regulation could benefit greatly through the use of shared concepts and models for motif evolution at the transcriptional, post-transcriptional and post-translational level (e.g., $[35,65,107])$.

\section{Competing interests}

The authors declare that they have no competing interests.

\section{Authors' contributions}

NED MSC AMM conceived the manuscript. NED MSC AMM wrote the manuscript. All authors read and approved the final manuscript.

\section{Acknowledgements}

We apologise to all colleagues whose work could not be cited here owing to space restrictions. NED is supported by a SFI Starting Investigator Research Grant (13/SIRG/2193). MSC is supported by NIH grant GM-48728. AMM is supported by grants from the National Sciences and Engineering Research Council (NSERC). We thank Richard Edwards, Hunter Fraser, Toby Gibson, Aino Järvelin, Christian Landry, Denis Shields, Kim Van Roey and Taraneh Zarin for fruitful discussions and critically reading the manuscript.

\section{Author details}

${ }^{1}$ Conway Institute of Biomolecular and Biomedical Sciences, University College Dublin, Dublin 4, Ireland. ${ }^{2}$ Department of Biology, Stanford University, Stanford, CA 94305, USA. ${ }^{3}$ Department of Cell \& Systems Biology, University of Toronto, Toronto, Canada. ${ }^{4}$ Centre for the Analysis of Genome Evolution and Function, University of Toronto, Toronto, Canada.

Received: 21 June 2015 Accepted: 13 November 2015

Published online: 21 November 2015

\section{References}

1. Bejerano G, Haussler D, Blanchette M. Into the heart of darkness: large-scale clustering of human non-coding DNA. Bioinformatics. 2004;20 Suppl 1:140-8.

2. Gerstein MB, Lu ZI, Van Nostrand EL, Cheng C, Arshinoff BI, Liu T, et al. Integrative analysis of the Caenorhabditis elegans genome by the modENCODE project. Science. 2010:330(6012):1775-87.

3. Roy S, Ernst J, Kharchenko PV, Kheradpour P, Negre N, Eaton ML, et al. Identification of functional elements and regulatory circuits by Drosophila modENCODE. Science. 2010;330(6012):1787-97.
4. An integrated encyclopedia of DNA elements in the human genome. Nature. 2012:489(7414):57-74

5. Tompa P. Intrinsically unstructured proteins. Trends Biochem Sci. 2002; 27(10):527-33.

6. Dyson $\mathrm{HJ}$, Wright PE. Intrinsically unstructured proteins and their functions. Nat Rev Mol Cell Biol. 2005;6(3):197-208

7. Tompa P. Unstructural biology coming of age. Curr Opin Struct Biol. 2011; 21(3):419-25.

8. Tompa P. Intrinsically disordered proteins: a 10-year recap. Trends Biochem Sci. 2012;37(12):509-16.

9. Dinkel H, Van Roey K, Michael S, Davey NE, Weatheritt RJ, Born D, et al. The eukaryotic linear motif resource ELM: 10 years and counting. Nucleic Acids Res. 2014;42(Database issue):D259-66.

10. Van Roey K, Uyar B, Weatheritt RJ, Dinkel H, Seiler M, Budd A, et al. Short linear motifs: ubiquitous and functionally diverse protein interaction modules directing cell regulation. Chem Rev. 2014;114(13):6733-78.

11. Wright PE, Dyson HJ. Intrinsically disordered proteins in cellular signalling and regulation. Nat Rev Mol Cell Biol. 2015;16(1):18-29.

12. Van Roey K, Gibson TJ, Davey NE. Motif switches: decision-making in cell regulation. Curr Opin Struct Biol. 2012;22(3):378-85

13. Davey NE, Van Roey K, Weatheritt RJ, Toedt G, Uyar B, Altenberg B, et al. Attributes of short linear motifs. Mol BioSyst. 2012;8(1):268-81.

14. Stein A, Aloy P. Contextual specificity in peptide-mediated protein interactions. PLoS One. 2008;3(7):e2524.

15. Tompa P, Davey NE, Gibson TJ, Babu MM. A million peptide motifs for the molecular biologist. Mol Cell. 2014;55(2):161-9.

16. Neduva V, Russell RB. Linear motifs: evolutionary interaction switches. FEBS Lett. 2005;579(15):3342-5

17. Vogel C, Bashton M, Kerrison ND, Chothia C, Teichmann SA. Structure, function and evolution of multidomain proteins. Curr Opin Struct Biol. 2004; 14(2):208-16.

18. Wray GA, Hahn MW, Abouheif E, Balhoff JP, Pizer M, Rockman MV, et al. The evolution of transcriptional regulation in eukaryotes. Mol Biol Evol. 2003; 20(9):1377-419.

19. Glotzer M, Murray AW, Kirschner MW. Cyclin is degraded by the ubiquitin pathway. Nature. 1991;349(6305):132-8.

20. Pidoux AL, Armstrong J. Analysis of the BiP gene and identification of an ER retention signal in Schizosaccharomyces pombe. EMBO J. 1992;11(4):1583-91.

21. Bu JY, Shaw AS, Chan AC. Analysis of the interaction of ZAP-70 and syk protein-tyrosine kinases with the T-cell antigen receptor by plasmon resonance. Proc Natl Acad Sci U S A. 1995;92(11):5106-10.

22. Edwards AS, Newton AC. Phosphorylation at conserved carboxyl-terminal hydrophobic motif regulates the catalytic and regulatory domains of protein kinase C. J Biol Chem. 1997;272(29):18382-90.

23. Puntervoll P, Linding R, Gemund C, Chabanis-Davidson S, Mattingsdal M, Cameron S, et al. ELM server: A new resource for investigating short functional sites in modular eukaryotic proteins. Nucleic Acids Res. 2003; 31(13):3625-30.

24. Warbrick E, Lane DP, Glover DM, Cox LS. Homologous regions of Fen1 and p21Cip1 compete for binding to the same site on PCNA: a potential mechanism to co-ordinate DNA replication and repair. Oncogene. 1997;14(19):2313-21.

25. Dionne I, Nookala RK, Jackson SP, Doherty AJ, Bell SD. A heterotrimeric PCNA in the hyperthermophilic archaeon Sulfolobus solfataricus. Mol Cell. 2003;11(1):275-82.

26. Cordeddu V, Di Schiavi E, Pennacchio LA, Ma'ayan A, Sarkozy A, Fodale V et al. Mutation of SHOC2 promotes aberrant protein $\mathrm{N}$-myristoylation and causes Noonan-like syndrome with loose anagen hair. Nat Genet. 2009; 41(9):1022-6.

27. Goldman A, Roy J, Bodenmiller B, Wanka S, Landry CR, Aebersold R, et al. The calcineurin signaling network evolves via conserved kinasephosphatase modules that transcend substrate identity. Mol Cell. 2014; 55(3):422-35.

28. Zielinska DF, Gnad F, Schropp K, Wisniewski JR, Mann M. Mapping $\mathrm{N}$-glycosylation sites across seven evolutionarily distant species reveals a divergent substrate proteome despite a common core machinery. Mol Cell. 2012:46(4):542-8.

29. Holt LJ, Tuch BB, Villen J, Johnson AD, Gygi SP, Morgan DO. Global analysis of Cdk1 substrate phosphorylation sites provides insights into evolution. Science. 2009;325(5948):1682-6.

30. Beltrao P, Serrano L. Specificity and evolvability in eukaryotic protein interaction networks. PLoS Comput Biol. 2007;3(2):e25. 
31. Kim J, Kim I, Yang JS, Shin YE, Hwang J, Park S, et al. Rewiring of PDZ domain-ligand interaction network contributed to eukaryotic evolution. PLoS Genet. 2012;8(2):e1002510.

32. Xin X, Gfeller D, Cheng J, Tonikian R, Sun L, Guo A, et al. SH3 interactome conserves general function over specific form. Mol Syst Biol. 2013;9:652.

33. Sun MG, Sikora M, Costanzo M, Boone C, Kim PM. Network evolution: rewiring and signatures of conservation in signaling. PLoS Comput Biol. 2012;8(3):e1002411.

34. Crawford ED, Seaman JE, Barber 2nd AE, David DC, Babbitt PC, Burlingame $A L$, et al. Conservation of caspase substrates across metazoans suggests hierarchical importance of signaling pathways over specific targets and cleavage site motifs in apoptosis. Cell Death Differ. 2012;19(12):2040-8.

35. Moses AM, Landry CR. Moving from transcriptional to phospho-evolution: generalizing regulatory evolution? Trends Genet. 2010;26(11):462-7.

36. Nguyen Ba AN, Strome B, Hua JJ, Desmond J, Gagnon-Arsenault I, Weiss EL, et al. Detecting functional divergence after gene duplication through evolutionary changes in posttranslational regulatory sequences. PLoS Comput Biol. 2014;10(12):e1003977.

37. Conant GC, Wolfe KH. Turning a hobby into a job: how duplicated genes find new functions. Nat Rev Genet. 2008;9(12):938-50.

38. Boutros R, Lobjois V, Ducommun B. CDC25 phosphatases in cancer cells: key players? Good targets? Nat Rev Cancer. 2007;7(7):495-507.

39. Besson A, Dowdy SF, Roberts JM. CDK inhibitors: cell cycle regulators and beyond. Dev Cell. 2008;14(2):159-69.

40. Di Fiore B, Davey NE, Hagting A, Izawa D, Mansfeld J, Gibson TJ, et al. The ABBA motif binds APC/C activators and is shared by APC/C substrates and regulators. Dev Cell. 2015;32(3):358-72

41. Suijkerbuijk SJ, van Dam TJ, Karagoz GE, von Castelmur E, Hubner NC, Duarte AM, et al. The vertebrate mitotic checkpoint protein BUBR1 is an unusual pseudokinase. Dev Cell. 2012;22(6):1321-9.

42. Murray AW. Don't make me mad, Bub! Dev Cell. 2012;22(6):1123-5.

43. Carvunis AR, Rolland T, Wapinski I, Calderwood MA, Yildirim MA, Simonis N, et al. Proto-genes and de novo gene birth. Nature. 2012;487(7407):370-4

44. Kirchhoff F. Is the high virulence of HIV-1 an unfortunate coincidence of primate lentiviral evolution? Nat Rev Microbiol. 2009;7(6):467-76.

45. Besnard-Guerin C, Belaidouni N, Lassot I, Segeral E, Jobart A, Marchal C, et al. HIV-1 Vpu sequesters beta-transducin repeat-containing protein (betaTrCP) in the cytoplasm and provokes the accumulation of beta-catenin and other SCFbetaTrCP substrates. J Biol Chem. 2004;279(1):788-95.

46. Davey NE, Trave G, Gibson TJ. How viruses hijack cell regulation. Trends Biochem Sci. 2011;36(3):159-69.

47. Kaneko T, Huang H, Cao X, Li X, Li C, Voss C, et al. Superbinder SH2 domains act as antagonists of cell signaling. Sci Signal. 2012;5(243):ra68.

48. Alexander J, Lim D, Joughin BA, Hegemann B, Hutchins JR, Ehrenberger $T$, et al. Spatial exclusivity combined with positive and negative selection of phosphorylation motifs is the basis for context-dependent mitotic signaling. Sci Signal. 2011;4(179):ra42

49. Liu BA, Engelmann BW, Nash PD. The language of $\mathrm{SH} 2$ domain interactions defines phosphotyrosine-mediated signal transduction. FEBS Lett. 2012; 586(17):2597-605.

50. Li H, Rao A, Hogan PG. Structural delineation of the calcineurin-NFAT interaction and its parallels to PP1 targeting interactions. J Mol Biol. 2004; 342(5):1659-74.

51. Roy J, Li H, Hogan PG, Cyert MS. A conserved docking site modulates substrate affinity for calcineurin, signaling output, and in vivo function. Mol Cell. 2007;25(6):889-901.

52. Marles JA, Dahesh S, Haynes J, Andrews BJ, Davidson AR. Protein-protein interaction affinity plays a crucial role in controlling the Sho1p-mediated signal transduction pathway in yeast. Mol Cell. 2004;14(6):813-23.

53. Zarrinpar A, Park SH, Lim WA. Optimization of specificity in a cellular protein interaction network by negative selection. Nature. 2003;426(6967):676-80.

54. Moses AM, Liku ME, Li JJ, Durbin R. Regulatory evolution in proteins by turnover and lineage-specific changes of cyclin-dependent kinase consensus sites. Proc Natl Acad Sci U S A. 2007;104(45):17713-8.

55. Van Roey K, Dinkel H, Weatheritt RJ, Gibson TJ, Davey NE. The switches.ELM resource: a compendium of conditional regulatory interaction interfaces. Sci Signal. 2013;6(269):rs7.

56. Hirschi A, Cecchini M, Steinhardt RC, Schamber MR, Dick FA, Rubin SM. An overlapping kinase and phosphatase docking site regulates activity of the retinoblastoma protein. Nat Struct Mol Biol. 2010;17(9):1051-7.
57. Drury LS, Diffley JF. Factors affecting the diversity of DNA replication licensing control in eukaryotes. Curr Biol. 2009;19(6):530-5.

58. Lyons NA, Fonslow BR, Diedrich JK, Yates 3rd JR, Morgan DO. Sequential primed kinases create a damage-responsive phosphodegron on Eco1. Nat Struct Mol Biol. 2013;20(2):194-201.

59. Han JH, Batey S, Nickson AA, Teichmann SA, Clarke J. The folding and evolution of multidomain proteins. Nat Rev Mol Cell Biol. 2007:8(4): 319-30.

60. Tompa P, Fuxreiter M, Oldfield CJ, Simon I, Dunker AK, Uversky VN. Close encounters of the third kind: disordered domains and the interactions of proteins. Bioessays. 2009;31(3):328-35.

61. Brown CJ, Takayama S, Campen AM, Vise P, Marshall TW, Oldfield CJ, et al. Evolutionary rate heterogeneity in proteins with long disordered regions. J Mol Evol. 2002;55(1):104-10.

62. Fuxreiter M, Tompa P, Simon I. Local structural disorder imparts plasticity on linear motifs. Bioinformatics. 2007;23(8):950-6.

63. Borcherds W, Theillet FX, Katzer A, Finzel A, Mishall KM, Powell AT, et al. Disorder and residual helicity alter p53-Mdm2 binding affinity and signaling in cells. Nat Chem Biol. 2014;10(12):1000-2.

64. Scott JD, Pawson T. Cell signaling in space and time: where proteins come together and when they're apart. Science. 2009;326(5957):1220-4.

65. Levy ED, Landry CR, Michnick SW. How perfect can protein interactomes be? Sci Signal. 2009;2(60):e11.

66. Jones RB, Gordus A, Krall JA, MacBeath G. A quantitative protein interaction network for the ErbB receptors using protein microarrays. Nature. 2006; 439(7073):168-74.

67. Peti W, Nairn AC, Page R. Structural basis for protein phosphatase 1 regulation and specificity. FEBS J. 2013;280(2):596-611.

68. Mitrea DM, Yoon MK, Ou L, Kriwacki RW. Disorder-function relationships for the cell cycle regulatory proteins p21 and p27. Biol Chem. 2012;393(4):259-74.

69. He J, Chao WC, Zhang Z, Yang J, Cronin N, Barford D. Insights into degron recognition by APC/C coactivators from the structure of an Acm1-Cdh1 complex. Mol Cell. 2013;50(5):649-60.

70. Nair R, Carter P, Rost B. NLSdb: database of nuclear localization signals. Nucleic Acids Res. 2003;31(1):397-9.

71. Yamano H, Gannon J, Hunt T. The role of proteolysis in cell cycle progression in Schizosaccharomyces pombe. EMBO J. 1996;15(19):5268-79.

72. Rape M, Reddy SK, Kirschner MW. The processivity of multiubiquitination by the APC determines the order of substrate degradation. Cell. 2006;124(1): 89-103.

73. Kielkopf CL, Rodionova NA, Green MR, Burley SK. A novel peptide recognition mode revealed by the X-ray structure of a core U2AF35/U2AF65 heterodimer. Cell. 2001;106(5):595-605.

74. Stirnimann CU, Petsalaki E, Russell RB, Muller CW. WD40 proteins propel cellular networks. Trends Biochem Sci. 2010;35(10):565-74.

75. Gogl G, Schneider KD, Yeh BJ, Alam N, Nguyen Ba AN, Moses AM, et al. The Structure of an NDR/LATS Kinase-Mob Complex Reveals a Novel Kinase-Coactivator System and Substrate Docking Mechanism. PLoS Biol. 2015;13(5):e1002146.

76. Conti E, Kuriyan J. Crystallographic analysis of the specific yet versatile recognition of distinct nuclear localization signals by karyopherin alpha. Structure. 2000;8(3):329-38.

77. Zamir L, Zaretsky M, Fridman Y, Ner-Gaon H, Rubin E, Aharoni A. Tight coevolution of proliferating cell nuclear antigen (PCNA)-partner interaction networks in fungi leads to interspecies network incompatibility. Proc Natl Acad Sci U S A. 2012;109(7):E406-14.

78. Lu D, Hsiao JY, Davey NE, Van Voorhis VA, Foster SA, Tang C, et al. Multiple mechanisms determine the order of APC/C substrate degradation in mitosis. BioMed Res Int. 2014:207(1):23-39.

79. Tonikian R, Zhang Y, Sazinsky SL, Currell B, Yeh JH, Reva B, et al. A specificity map for the PDZ domain family. PLoS Biol. 2008;6(9):e239.

80. Kaneko T, Sidhu SS, Li SS. Evolving specificity from variability for protein interaction domains. Trends Biochem Sci. 2011;36(4):183-90.

81. Ubersax JA, Ferrell Jr JE. Mechanisms of specificity in protein phosphorylation. Nat Rev Mol Cell Biol. 2007;8(7):530-41.

82. Mok J, Kim PM, Lam HY, Piccirillo S, Zhou X, Jeschke GR, et al. Deciphering protein kinase specificity through large-scale analysis of yeast phosphorylation site motifs. Sci Signal. 2010;3(109):ra12.

83. Howard CJ, Hanson-Smith V, Kennedy KJ, Miller CJ, Lou HJ, Johnson AD et al. Ancestral resurrection reveals evolutionary mechanisms of kinase plasticity. 2014;3. doi: 10.7554/eLife.04126 
84. Huang H, Li L, Wu C, Schibli D, Colwill K, Ma S, et al. Defining the specificity space of the human SRC homology 2 domain. Mol Cell Proteomics. 2008; 7(4):768-84.

85. Liu BA, Nash PD. Evolution of $\mathrm{SH} 2$ domains and phosphotyrosine signalling networks. Philos Trans R Soc Lond Ser B Biol Sci. 2012;367(1602):2556-73.

86. Stiffler MA, Chen JR, Grantcharova VP, Lei Y, Fuchs D, Allen JE, et al. PDZ domain binding selectivity is optimized across the mouse proteome. Science. 2007;317(5836):364-9.

87. Zhu G, Fujii K, Belkina N, Liu Y, James M, Herrero J, et al. Exceptional disfavor for proline at the $\mathrm{P}+1$ position among AGC and CAMK kinases establishes reciprocal specificity between them and the proline-directed kinases. J Biol Chem. 2005;280(11):10743-8.

88. Zarrinpar A, Bhattacharyya RP, Lim WA. The structure and function of proline recognition domains. Sci STKE. 2003;2003(179):Re8.

89. Seet BT, Dikic I, Zhou MM, Pawson T. Reading protein modifications with interaction domains. Nat Rev Mol Cell Biol. 2006;7(7):473-83.

90. Ivarsson Y. Plasticity of PDZ domains in ligand recognition and signaling. FEBS Lett. 2012;586(17):2638-47.

91. Dalrymple BP, Kongsuwan K, Wijfels G, Dixon NE, Jennings PA. A universal protein-protein interaction motif in the eubacterial DNA replication and repair systems. Proc Natl Acad Sci U S A. 2001;98(20):11627-32.

92. Gorna MW, Carpousis AJ, Luisi BF. From conformational chaos to robust regulation: the structure and function of the multi-enzyme RNA degradosome. Q Rev Biophys. 2012;45(2):105-45.

93. Schad $\mathrm{E}$, Tompa $\mathrm{P}$, Hegyi $\mathrm{H}$. The relationship between proteome size, structural disorder and organism complexity. Genome Biol. 2011;12(12):R120.

94. Sakarya O, Conaco C, Egecioglu O, Solla SA, Oakley TH, Kosik KS. Evolutionary expansion and specialization of the PDZ domains. Mol Biol Evol. 2010;27(5):1058-69.

95. Vogel C, Chothia C. Protein family expansions and biological complexity. PLoS Comput Biol. 2006;2(5):e48.

96. Pincus D, Letunic I, Bork P, Lim WA. Evolution of the phospho-tyrosine signaling machinery in premetazoan lineages. Proc Natl Acad Sci U S A. 2008;105(28):9680-4.

97. Weingarten-Gabbay S, Segal E. The grammar of transcriptional regulation. Hum Genet. 2014;133(6):701-11.

98. Fu XD, Ares Jr M. Context-dependent control of alternative splicing by RNAbinding proteins. Nat Rev Genet. 2014;15(10):689-701.

99. Friedman Y, Balaga O, Linial M. Working together: combinatorial regulation by microRNAs. Adv Exp Med Biol. 2013;774:317-37.

100. Baker CR, Tuch BB, Johnson AD. Extensive DNA-binding specificity divergence of a conserved transcription regulator. Proc Natl Acad Sci U S A. 2011;108(18):7493-8.

101. Ballester B, Medina-Rivera A, Schmidt D, Gonzalez-Porta M, Carlucci M, Chen $X$, et al. Multi-species, multi-transcription factor binding highlights conserved control of tissue-specific biological pathways. eLife. 2014;3: e02626.

102. Ruths T, Nakhleh L. ncDNA and drift drive binding site accumulation. BMC Evol Biol. 2012;12:159.

103. He BZ, Holloway AK, Maerkl SJ, Kreitman M. Does positive selection drive transcription factor binding site turnover? A test with Drosophila cis-regulatory modules. PLoS Genet. 2011;7(4):e1002053.

104. Lynch $M$. The frailty of adaptive hypotheses for the origins of organismal complexity. Proc Natl Acad Sci U S A. 2007;104 Suppl 1:8597-604.

105. Ivarsson Y, Arnold R, McLaughlin M, Nim S, Joshi R, Ray D, et al. Large-scale interaction profiling of PDZ domains through proteomic peptide-phage display using human and viral phage peptidomes. Proc Natl Acad Sci U S A. 2014;111(7):2542-7.

106. Sundell GN, Ivarsson $Y$. Interaction analysis through proteomic phage display. BioMed Res Int. 2014;2014:176172.

107. Landry CR, Freschi L, Zarin T, Moses AM. Turnover of protein phosphorylation evolving under stabilizing selection. Front Genet. 2014; 5:245.

108. Hedges SB, Dudley J, Kumar S. TimeTree: a public knowledge-base of divergence times among organisms. Bioinformatics. 2006;22(23):2971-2.

109. Takeuchi K, Roehrl MH, Sun ZY, Wagner G. Structure of the calcineurin-NFAT complex: defining a T cell activation switch using solution NMR and crystal coordinates. Structure. 2007;15(5):587-97.

110. Li H, Pink MD, Murphy JG, Stein A, Dell'Acqua ML, Hogan PG. Balanced interactions of calcineurin with AKAP79 regulate Ca2 + -calcineurin-NFAT signaling. Nat Struct Mol Biol. 2012;19(3):337-45.
111. Czirjak G, Enyedi P. Targeting of calcineurin to an NFAT-like docking site is required for the calcium-dependent activation of the background $\mathrm{K}_{+}$ channel, TRESK. J Biol Chem. 2006;281(21):14677-82.

112. Bultynck G, Heath VL, Majeed AP, Galan JM, Haguenauer-Tsapis R, Cyert MS. SIm1 and slm2 are novel substrates of the calcineurin phosphatase required for heat stress-induced endocytosis of the yeast uracil permease. Mol Cell Biol. 2006;26(12):4729-45.

113. Heath VL, Shaw SL, Roy S, Cyert MS. Hph1p and Hph2p, novel components of calcineurin-mediated stress responses in Saccharomyces cerevisiae. Eukaryot Cell. 2004;3(3):695-704.

114. Boustany LM, Cyert MS. Calcineurin-dependent regulation of Crz1p nuclear export requires Msn5p and a conserved calcineurin docking site. Genes Dev. 2002;16(5):608-19.

115. Grigoriu S, Bond R, Cossio P, Chen JA, Ly N, Hummer G, et al. The molecular mechanism of substrate engagement and immunosuppressant inhibition of calcineurin. PLoS Biol. 2013;11(2):e1001492.

116. Li H, Zhang L, Rao A, Harrison SC, Hogan PG. Structure of calcineurin in complex with PVIVIT peptide: portrait of a low-affinity signalling interaction. J Mol Biol. 2007;369(5):1296-306.

117. Zhang T, Prives C. Cyclin a-CDK phosphorylation regulates MDM2 protein interactions. J Biol Chem. 2001;276(32):29702-10.

118. Igarashi M, Ito K, Kida H, Takada A. Genetically destined potentials for $\mathrm{N}$-linked glycosylation of influenza virus hemagglutinin. Virology. 2008; 376(2):323-9.

119. Kissinger CR, Liu BS, Martin-Blanco E, Kornberg TB, Pabo CO. Crystal structure of an engrailed homeodomain-DNA complex at $2.8 \mathrm{~A}$ resolution: a framework for understanding homeodomain-DNA interactions. Cell. 1990;63(3):579-90.

120. Clery A, Jayne S, Benderska N, Dominguez C, Stamm S, Allain FH. Molecular basis of purine-rich RNA recognition by the human SR-like protein Tra2-beta1. Nat Struct Mol Biol. 2011;18(4):443-50.

121. Wu X, Knudsen B, Feller SM, Zheng J, Sali A, Cowburn D, et al. Structural basis for the specific interaction of lysine-containing prolinerich peptides with the N-terminal SH3 domain of c-Crk. Structure. 1995; 3(2):215-26

122. Pornillos O, Alam SL, Davis DR, Sundquist WI. Structure of the Tsg101 UEV domain in complex with the PTAP motif of the HIV-1 p6 protein. Nat Struct Biol. 2002;9(11):812-7.

123. Hao B, Oehlmann S, Sowa ME, Harper JW, Pavletich NP. Structure of a Fbw7-Skp1-cyclin E complex: multisite-phosphorylated substrate recognition by SCF ubiquitin ligases. Mol Cell. 2007;26(1):131-43.

124. Ray D, Kazan H, Cook KB, Weirauch MT, Najafabadi HS, Li X, et al. A compendium of RNA-binding motifs for decoding gene regulation. Nature. 2013;499(7457):172-7.

125. Lunde BM, Moore C, Varani G. RNA-binding proteins: modular design for efficient function. Nat Rev Mol Cell Biol. 2007;8(6):479-90.

126. Lewis BP, Burge CB, Bartel DP. Conserved seed pairing, often flanked by adenosines, indicates that thousands of human genes are microRNA targets. Cell. 2005;120(1):15-20.

127. Wolfe SA, Nekludova L, Pabo CO. DNA recognition by Cys $2 \mathrm{His} 2$ zinc finger proteins. Annu Rev Biophys Biomol Struct. 2000;29:183-212.

128. Catron KM, ller N, Abate C. Nucleotides flanking a conserved TAAT core dictate the DNA binding specificity of three murine homeodomain proteins. Mol Cell Biol. 1993;13(4):2354-65.

129. Bi W, Wu L, Coustry F, de Crombrugghe B, Maity SN. DNA binding specificity of the CCAAT-binding factor CBF/NF-Y. J Biol Chem. 1997;272(42): 26562-72.

130. Menendez D, Inga A, Resnick MA. The expanding universe of p53 targets. Nat Rev Cancer. 2009;9(10):724-37.

131. Wu G, Xu G, Schulman BA, Jeffrey PD, Harper JW, Pavletich NP. Structure of a beta-TrCP1-Skp1-beta-catenin complex: destruction motif binding and lysine specificity of the SCF(beta-TrCP1) ubiquitin ligase. Mol Cell. 2003;11(6): 1445-56.

132. Jennings BH, Pickles LM, Wainwright SM, Roe SM, Pearl LH, Ish-Horowicz D. Molecular recognition of transcriptional repressor motifs by the WD domain of the Groucho/TLE corepressor. Mol Cell. 2006;22(5):645-55.

133. Terrak M, Kerff F, Langsetmo K, Tao T, Dominguez R. Structural basis of protein phosphatase 1 regulation. Nature. 2004;429(6993):780-4.

134. Hittinger CT, Carroll SB. Evolution of an insect-specific GROUCHOinteraction motif in the ENGRAILED selector protein. Evol Dev. 2008;10(5):537-45 
135. Kusari AB, Molina DM, Sabbagh Jr W, Lau CS, Bardwell L. A conserved protein interaction network involving the yeast MAP kinases Fus3 and Kss1. J Cell Biol. 2004;164(2):267-77.

136. Lowe ED, Tews I, Cheng KY, Brown NR, Gul S, Noble ME, et al. Specificity determinants of recruitment peptides bound to phospho-CDK2/cyclin A. Biochemistry. 2002;41(52):15625-34.

Submit your next manuscript to BioMed Central and we will help you at every step:

- We accept pre-submission inquiries

- Our selector tool helps you to find the most relevant journal

- We provide round the clock customer support

- Convenient online submission

- Thorough peer review

- Inclusion in PubMed and all major indexing services

- Maximum visibility for your research 